\title{
Inter-annual variations in the floristic and population structure of an herbaceous community of "caatinga" vegetation in Pernambuco, Brazil"
}

\author{
ANA MARIA S. REIS ${ }^{2}$, ELCIDA L. ARAÚJO', ${ }^{2,4}$ ELBA MARIA N. FERRAZ ${ }^{3}$ and \\ ARIADNE N. MOURA ${ }^{2}$
}

(received: August 5, 2004; accepted: August 24, 2006)

\begin{abstract}
Inter-annual variations in the floristic and population structure of an herbaceous community of "caatinga" in Pernambuco, Brazil). The influence of climatic variations on the herbaceous component of the "caatinga" vegetation was examined in the state of Pernambuco, Brazil. A total of $1051 \times 1 \mathrm{~m}$-plots were established, of which 35 were in a level micro-habitat, 35 in a riparian micro-habitat, and 35 in a stony microhabitat. During two consecutive years all herbaceous plants in these plots were counted, measured (height and diameter), and collected for identification. The Shannon-Wiener diversity index and the equitability were calculated for each year, as well as the density, frequency, dominance, total basal area and importance index for each species. The total annual pluviometric was 819.5 and $448.8 \mathrm{~mm}$ in 2002 and 2003, respectively. The herbaceous flora in the study area was composed of 71 species, of which 58 were sampled in the plots. The families with the greatest species richness were Malvaceae (8 species), Euphorbiaceae (7), Poaceae (6), Convolvulaceae (4), Fabaceae (4), and Portulacaceae (4). The diversity indices were 2.66 and 3.01 nats ind $^{-1}$ in 2002 and 2003, respectively. The density, frequency, dominance and importance value of herbaceous populations, as well as, the height and diameter of plants were low in the dryer year. The riparian group was the most isolated of the microhabitats examined, both in terms of its floristic and its population structure. Annual seasonal climatic variations greatly modified these populations structure during the course of this study, emphasizing the fact that longterm studies are needed in order to better understand the dynamics of the herbaceous component of the "caatinga" vegetation.
\end{abstract}

Key words - "caatinga", herbaceous component, phytosociology, seasonal climate changes, species richness

RESUMO - (Variações interanuais na composição florística e estrutura das populações de uma comunidade herbácea da caatinga, Pernambuco, Brasil). Objetivou-se avaliar a influência das variações climáticas sobre o componente herbáceo em uma área de caatinga de Pernambuco. Foram estabelecidas 105 parcelas de $1 \times 1 \mathrm{~m}$, sendo 35 dispostas em micro-habitat plano, 35 em micro-habitat ciliar e $35 \mathrm{em}$ micro-habitat rochoso. Durante dois anos consecutivos todas as ervas presentes nas parcelas foram contadas, medidas (altura e diâmetro) e coletadas para identificação taxonômica. Foram calculados o índice de diversidade Shannon-Wiener, a equabilidade e os parâmetros de densidade, freqüência, dominância, área basal total e índice de valor de importância. A precipitação pluviométrica anual registrada foi de 819,5e 448,8 mm em 2002 e 2003, respectivamente. A flora herbácea registrada nas parcelas e fora delas foi representada por 71 espécies, sendo 58 amostradas. As famílias de maior riqueza de espécies foram Malvaceae (8), Euphorbiaceae (7), Poaceae (6), Convolvulaceae (4), Fabaceae (4) e Portulacaceae (4). As diversidades foram de 2,66 e 3,01 nats ind ${ }^{-1} \mathrm{em} 2002$ e 2003, respectivamente. A densidade, frequiência, dominância e valor de importância das populações herbáceas, bem como, a altura e o diâmetro das plantas foram menores no ano mais seco. Entre os micro-habitats, o ciliar formou um grupo mais isolado quanto a florística e estrutura das populações, quando comparado com os demais micro-habitats. A sazonalidade climática interanual provocou alterações de forma moderada a drástica no tamanho das populações entre os anos. Séries temporais curtas não são suficientes para conhecer a dinâmica regenerativa do componente herbáceo da caatinga.

Palavras-chave - caatinga, componente herbáceo, fitossociologia, riqueza de espécies, sazonalidade climática

\section{Introduction}

"Caatinga" is a type of deciduous, dry forest vegetation that experiences a dry period lasting from 3

1. Parte da dissertação de mestrado do primeiro autor, Programa de Pós-Graduação em Botânica da Universidade Federal Rural de Pernambuco.

2. Universidade Federal Rural de Pernambuco, Departamento de Biologia, Av. Dom Manoel de Medeiros s/n, Dois Irmãos, 52171-900 Recife, PE, Brazil.

3. Centro Federal de Educação Tecnológica de Pernambuco, Av. Nelson Chaves s/n, 50372-970 Recife, PE, Brazil.

4. Corresponding author: elcida@ufrpe.br to 8 months. It occupies most of northeastern Brazil (Araújo 1998, Sampaio 2003, Ferraz et al. 2003), where total annual pluviometric indices are low, although different regions may have their own characteristic average. Years with total pluviometric above and under the average were recorded for "caatinga" vegetation but inter-annual fluctuations in rainfall are unpredictable, and may be extreme (Sampaio 2003, Araújo 2005), and will influence comparative studies on plant community dynamics (Araújo 2005, Araújo et al. 2005a).

Previous research on the woody vegetation of the "caatinga" has shown that: 1) there are a great number 
of endemic species threatened with local extinction (Sampaio et al. 2002); 2) there are variations in species abundance between different habitats (Araújo \& Tabarelli 2002); 3) seasonal climatic changes alter the birth and death rates of the plant populations (Araújo 1998, Araújo et al. 2005a); 4) flowering and fruiting are most intense during the rainy season (Machado et al. 1997, Araújo \& Ferraz 2003) and, 5) many species have great economic value (Sampaio et al. 2002).

The herbaceous flora of the "caatinga" vegetation, however, is less well know, although previous studies have demonstrated that it: 1) retains the greater part of the biodiversity of the "caatinga" biome (Araújo et al. 2002, Araújo 2003); 2) is composed predominantly of terophytes plants, and is therefore most apparent during the rainy season (Pereira et al. 1989, Araújo 2003, Reis 2004, Silva 2004); 3) influences the dynamics of the woody vegetation component (Araújo 1998); 4) contains habitat-specific species (Reis 2004, Araújo et al. 2005b); 5) flowers and fruits most intensely during the raining season, like the woody vegetation (Pereira et al. 1989, Reis 2004, Silva 2004, Feitoza 2004) and 6) has great value as pasture, or for apiculture (Carvalho \& Marchini 1999, Sampaio et al. 2002, Lorenzon et al. 2003). It has been suggested that the herbaceous vegetation has an important role in maintaining the biodiversity of the woody component of the flora, as their roots help maintain the soil seedbank (Araújo 2003, Feitoza 2004).

In dry years few study on the vegetation was recorded because the majority of species is deciduous, and none was directed towards describing and comparing the influence of annual climatic variations on the structure of herbaceous plant populations in the "caatinga" biome. As such, the present work sought to characterize this flora, as well as quantify the influence of inter-annual variations climatic on regeneration processes of the herbaceous component in order to determine if there are observable differences in species composition and abundance in the populations. We expect that many alterations should occur within the community during regeneration as a majority of the species are annual plants, and that it will be possible to identify the populations that are most sensitive to climatic changes.

\section{Materials and methods}

Study area - This work was carried out during the years 2002 and 2003 in an area of "caatinga" vegetation, at the Experimental research station of the Empresa Pernambucana de Pesquisa Agropecuária (IPA) (8 14 ' S and 35 $55^{\circ}$ W; altitude
$537 \mathrm{~m}$ ), located in the municipality of Caruaru, Pernambuco State, Brazil. According to Alcoforado Filho et al. (2003), the soil there is classified as a yellow Podozol tb, eutrophic, abrupt, A moderated, franco-sandy texture, "caatinga" phase hipoxerophyte. The upper $(0-20 \mathrm{~cm})$ soil layer is composed of 631,229 , and $140 \mathrm{~g} \mathrm{~kg}^{-1}$ of sand, silt, and clay, respectively, as well as $6,6,25,11,43$, and $3 \mu \mathrm{mol} \mathrm{kg}{ }^{-1}$ of exchangeable $\mathrm{Na}, \mathrm{K}$, $\mathrm{Ca}, \mathrm{Mg}, \mathrm{H}$, and Al, respectively (Alcoforado Filho et al. 2003). The area is drained by the Olaria Stream, affluent of the Ipojuca River. Flow is very low during the dry season but higher in the rainy season, although there are no records of flooding.

The climate is seasonal, with an average total rainfall of $710 \mathrm{~mm}$. Temperatures vary between $11^{\circ} \mathrm{C}$ and $38^{\circ} \mathrm{C}$, with a compensated average of $22.7^{\circ} \mathrm{C}$. Climatic records over a 30 years period indicate that the rainy season generally occurs between March and August, with the rest of the year being essentially dry (Araújo 1998, Araújo et al. 2005a). This seasonality is reflected both in the deciduousness of the woody plants during the dry season, and in the growth of herbaceous plants only during the rainy season (Araújo et al. 2002, Sampaio 2003, Araújo et al. 2005a,b). During the study period, total annual recorded rainfall was $819.5 \mathrm{~mm}$ in 2002 , and $448.8 \mathrm{~mm}$ in 2003 (figure 1).

The total area covered by native vegetation in the Experimental research station is approximately 30 ha. Although the area of vegetation chosen in this study was continuous, it contained at least three microhabitats that were denominated: level, stony, and riparian. The level microhabitat constitutes areas of soil with a flat topography. Intermixed with the level microhabitat is the stony microhabitat, formed among discontinuous rocks varying in height from 0.3 to $1.10 \mathrm{~m}$, and covering 0.5 to $1.5 \mathrm{~m}^{2}$. Some of these stones are fissured, which permits the accumulation of soil, organic material, and water. The riparian microhabitat was located near the Olaria Stream, approximately 50 to $150 \mathrm{~m}$ from the other two microhabitats.

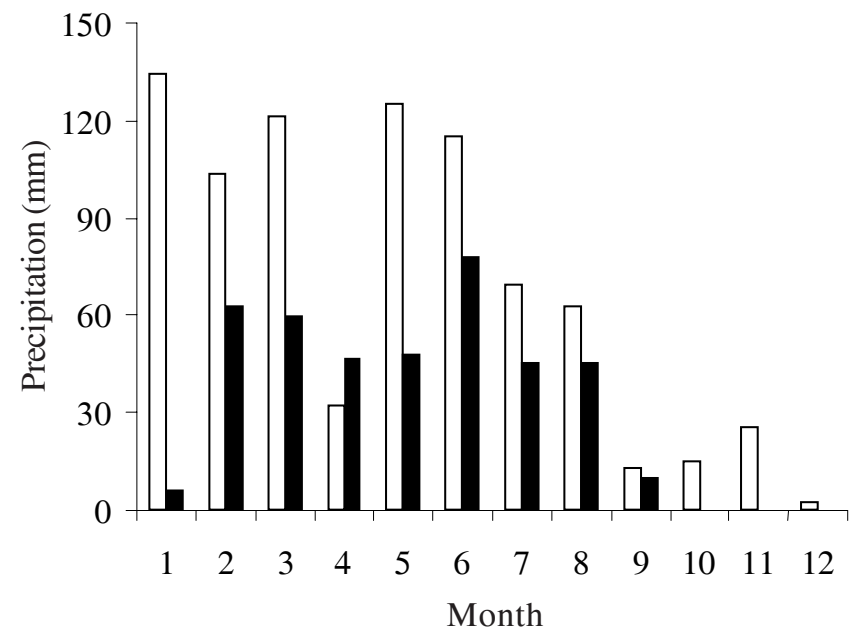

Figure 1. Monthly rainfall in the study area, during 2002 ( $\square$ ) and 2003 (ם). 
A dense, shrub-tree woody vegetation was dominant in all three microhabitats, and shading, which normally suppresses herbaceous coverage, was more or less homogeneous throughout. The woody vegetation was characterized principally by the presence of a number of species of Leguminosae and Euphorbiaceae, such as Caesalpinia pyramidalis Tul., Anadenanthera colubrina (Vell.) Brenam, Bauhinia cheilantha (Bong.) Steud, Croton sonderianus Müll. Arg., Jatropha mollissima (Pohl.) Baill., Manihot dichotoma Ule, and Sapium lanceolatum (Müll. Arg.) Herber (Alcoforado Filho et al. 2003). The herbaceous flora was dominated by numerous species of Poaceae, Asteraceae, Malvaceae, Convolvulaceae, and Euphorbiaceae (Araújo et al. 2002, Araújo et al. 2005b).

Data collection - The herbaceous stratum was surveyed in $351 \times 1 \mathrm{~m}$-plots in each of the three microhabitats (stony, level, and riparian), for a total of $105 \mathrm{~m}^{2}$. These $1 \times 1 \mathrm{~m}$-plots were randomly distributed within 400 permanent plots $(5 \times$ $5 \mathrm{~m}$ each) that were previously established at the Experimental station. As the stony and level microhabitats mix together naturally in the $5 \times 5 \mathrm{~m}$ permanent plots, they were posteriorly classified in the field by visual inspection after lottery selection. Lotteries were repeated until 35 plots were chosen for each microhabitat. Level area plots were always at least one meter from any rock outcrop. Stony plots were almost always located on distinct, individual outcrops. Riparian plots were established up to 10 meters from the river margin. The area studied had approximately $55 \%, 35 \%$ and $20 \%$ of its extension occupied by level, stony and riparian microhabitats, respectively. A census of all individuals in the herbaceous stratum in the selected plots was undertaken in 2002 and again in 2003. Total height and stem diameter were recorded for each plant. Measurements were made using a metric tape and a pachymeter. Plants were marked using plastic or wooden horticultural labels affixed either to the individual plants, or placed in the ground near them. Plants were considered herbaceous if they possessed a green stem and showed only low levels of lignification. Collections were made of all plants in their reproductive stage for purposes of taxonomic identification. Herbaceous species occurring near, but not within, the study plots were also registered, collected for identification, and listed as observed species.

Species not flowering during the sampling period were collected outside the plots and transplanted to a greenhouse. When flowering occurred, the plants were processed for identification. As some plants did not survive transplanting, monthly visits were also made to the sample plots to collect reproductive material of species that had not flowered during the sampling period. These procedures were repeated again in 2003 in order to examine annual differences in the regeneration of the herbaceous component of these communities.

Treatment and Data Analysis - All botanical material was prepared for storage in permanent collections (Mori et al. 1989) and identified using taxonomic keys, descriptions from specialized literature, as well as by comparison to material previously stored in the herbaria IPA, PEUFR and UFP. Specialists were consulted whenever necessary. The abbreviations of the authors' follow Brummit \& Powell (1992). Botanical material collected was incorporated into the PEUFR herbarium, and duplicates were sent to the IPA and UFP herbaria.

The data collected was used to compute ShannonWiener diversity indices and equitability (Krebs 1989, Araújo \& Ferraz 2004) as well as other phytosociological parameters (density, frequency, dominance, importance value and total basal area), using the Fitopac software package (Shepherd 1995). Difference between the Shannon-Wiener diversity indices was tested using $t$ test according to Hutcheson (Magurran 1989). Matrixes were prepared for the number of individuals of each species encountered in 2002 (42 species) and 2003 (50 species) in the level (plots 1 to 35), stony (plots 36 to 70 ), and riparian microhabitats (plots 71 to 105 ). The floristic-structural similarity between the microhabitats was assessed by cluster analysis techniques, using the BrayCurtis distance index and the average group link technique (UPGMA). This latter technique permits a greater correlation between the original and the calculated matrixes. This analysis was performed using the PC-ORD4 System program (McCune \& Mefford 1999). The causality between these links was tested using the Rand Mat 1.0 program for Windows, with 1000 repetitions of the Monte Carlo test, at a 5\% probability level.

Increases or decreases until $50 \%$ in population sizes between the two study years were considered "moderate" and above 50\%, "drastic", according to Reis (2004). Differences in the number of individuals in the different height and diameter classes, as well as the number of individuals sampled in each microhabitat in different years, were tested for all populations that had 5 or more individuals in at least one of the years through the chi-square test, at $5 \%$ probability (Zar 1996).

\section{Results and Discussion}

Annual variations in the structure and regeneration of the herbaceous component - The herbaceous flora was represented by 71 species during the study years, of which 58 species were sampled and 13 were observed near the sample plots. Of this total, $77 \%$ (55) were collected in the first year, and $83 \%$ (59) collected in the second year. Of these species, 57\% (41) were encountered in both years. In 2003, 16 species found were not been observed within the sample plots the previous year (table 1). These results emphasize the fact that short-term studies will not provide a complete view of the "caatinga" herbaceous flora, and confirms the observations of Araújo \& Ferraz (2003), Reis (2004) and Araújo et al. (2005b) that part of the biodiversity of 
this herbaceous component must be considered transitory. The species composing the herbaceous flora were distributed among 35 families and 63 genera. The year 2003 demonstrated the lowest family richness (27), but the largest species richness (table 1). In 2002, a total of 33 plant families were collected. Families with the greatest number of species were: Malvaceae (8 species), Euphorbiaceae (7), Poaceae (6), Convolvulaceae (4), Fabaceae (4), and Portulacaceae (4). These families have shown high diversity within the herbaceous stratum in other "caatinga" surveys (Santos 1987, Carvalho \& Marchini 1999, Araújo et al. 2002, Araújo 2003, Feitoza 2004, Silva 2004, Reis 2004, Araújo et al. 2005b).

The Shannon-Wiener diversity indices were 2.66 and 3.01 nats ind $^{-1}$ in 2002 and 2003, respectively. The difference between Shannon-Wiener indices recorded was significantly $(P<0.05)$. It is interesting to note that there does not seem to be a direct relationship between seasonality and alpha diversity, as the reduction in rainfall observed during the study years in this survey did not result in a loss of diversity. This result points to the need for long-term studies that can identify which factors are minimizing the full expression of alpha diversity in rainy years.

Equitability was very similar in both years $(0.71$ and 0.77 ) in spite of the differences in total rainfall. These values are relatively high compared to the only other reported phytosociological study during a dry year (0.28) by Feitoza (2004) but approach the range (0.55-0.72) variation that occurred in herbaceous vegetation of the "caatinga" (Silva 2004, Araújo et al. 2005b). The amplitude of these variations suggest that the distribution of the number of individuals of any species of herbaceous plant perhaps depends on local conditions and on the ability to exploit available resources during the short rainy season of "caatinga", because a majority of the herbaceous plants have a short life cycle, and so are influenced heavily by the characteristics of a single rainy season.

The total number of individuals sampled varied between years, and among sample plots. In 2002, there were 4,039 individuals in the $105 \mathrm{~m}^{2}$ total plot area. Densities varied from 2 to 135 individuals per $\mathrm{m}^{2}$. In 2003 , a total of 826 individuals were identified, varying from 0 to 40 individuals per $\mathrm{m}^{2}$. These values allowed us to estimate the local density of individuals as 38.5 and 7.9 ind $\mathrm{m}^{-2}$ in 2002 and 2003, respectively. These high densities agree with estimates of 30.0 to 161.3 ind $\mathrm{m}^{-2}$ for other herbaceous "caatinga" communities (Santos 1987, Feitoza 2004, Silva 2004,
Araújo et al. 2005) and corroborate well with the ideas that herbaceous plants have an important ecological function in conservation and retention seed bank soil, as well, to be important source of food for local fauna (Carvalho \& Marchini 1999, Lorenzon et al. 2003, Araújo \& Ferraz 2003, Araújo 2003, Feitoza 2004), because, although the individual plants have a very small aerial biomass, their high densities protect the soil from the direct incidence of sunlight and from the impact of the rain. However, considering that climatic variations can alter the annual herbs density, more studies in areas of "caatinga" with different physiognomies will be necessary in order to better define the role of herbaceous plants in this biome.

The total basal area of the herbaceous vegetation varied between years, reflecting the variations seen in plant densities. Basal area was 1.79 and $0.28 \mathrm{~m}^{2} \mathrm{ha}^{-1}$ in 2002 and 2003, respectively. These results demonstrate that during the process of regeneration there are natural alterations in the population structure of the herbaceous vegetation. These alterations are most probably related to the yearly variations in rainfall (figure 1), as the area did not experience any other obvious disturbances, such as fire, cutting, or grazing. This suggests the existence of a minimum critical rainfall value needed to generate equivalent patterns of land cover by herbaceous plants. As such, this study concludes that the observed variations in density and basal area reflect the yearly variations in weather patterns, and that short-term studies are not capable of accurately describing the regeneration dynamics of the herbaceous flora of the "caatinga".

The maximum heights of herbaceous species sampled were from 0.5 to $110 \mathrm{~cm}$. A majority of the plants $(84 \%)$ were $<15 \mathrm{~cm}$ tall, and the height distribution curve took the form of a reversed " $J$ " for both study years. Although there was a significant difference $\left(\chi^{2}=46.8, P<5 \%\right)$ in the height distribution curves in 2002 and 2003, the proportion of individuals in two the last classes was similar (figure 2A). This shows that the majority of all herbaceous plants was small, and suggests that the study area was well conserved, with recruitment of seedlings occurring at different times during the rainy season. In 2003 a majority of the herbaceous plants completed their life cycles while still diminutive, apparently in response to the dryer conditions of that year.

The maximum stem diameter of these herbs varied from 0.05 to $2.7 \mathrm{~cm}$, with a distribution skewed towards smaller diameters. Similar to the results for plant height, the diameter distribution curves during both study years 
Table 1. Families and species of herbaceous plants in an area of "caatinga" in Pernambuco State, Brazil, according to the importance value of the families in $2002\left(\mathrm{AD}=\right.$ Absolute Density, ind ha ${ }^{-1} ; \mathrm{ADo}=$ Absolute Dominance, $\mathrm{cm} \mathrm{ha}^{-1} ; \mathrm{AF}=\mathrm{Absolute}$ Frequency, \%; VI = Importance Value Index, \%; N. PEUFR = PEUFR Herbarium number).

\begin{tabular}{|c|c|c|c|c|c|c|c|c|c|}
\hline \multirow[t]{2}{*}{ Families/Species } & \multirow[b]{2}{*}{ N.PEUFR } & \multicolumn{4}{|c|}{2002} & \multicolumn{4}{|c|}{2003} \\
\hline & & $\mathrm{AD}$ & ADo & $\mathrm{AF}$ & VI & $\mathrm{AD}$ & ADo & $\mathrm{AF}$ & VI \\
\hline URTICACEAE & & 77524 & 55.144 & 42.860 & 58.850 & 95 & 0.030 & 0.950 & 0.580 \\
\hline Pilea hyalina Fenzl & 43413 & 77524 & 55.144 & 42.860 & 57.890 & 95 & 0.030 & 0.950 & 0.560 \\
\hline DIOSCOREACEAE & & 99238 & 6.791 & 86.670 & 45.930 & 12190 & 0.335 & 37.140 & 30.240 \\
\hline Dioscorea coronata Hauman & 43360 & 77333 & 5.028 & 81.900 & 36.590 & 10952 & 0.282 & 32.320 & 26.020 \\
\hline Dioscorea polygonoides Kunth & 43390 & 21905 & 1.675 & 21.900 & 10.270 & 1238 & 0.052 & 4.760 & 3.390 \\
\hline POACEAE & & 36285 & 32.062 & 48.570 & 36.400 & 10858 & 0.991 & 32.380 & 29.350 \\
\hline Panicum venezuellae Hack. & 43401 & 24857 & 11.1990 & 33.330 & 18.230 & 6667 & 0.580 & 24.760 & 19.130 \\
\hline Panicum maximum Jacq. & 43399 & 4667 & 19.786 & 7.620 & 13.460 & 667 & 0.0190 & 0.950 & 1.240 \\
\hline Panicum trichoides Swart & 43400 & 6190 & 1.067 & 20.000 & 5.530 & 1905 & 0.323 & 5.710 & 5.610 \\
\hline Enteropogon mollis (Ness) Clayton & 47375 & 571 & 0.017 & 2.860 & 0.630 & 1619 & 0.0684 & 6.67 & 4.59 \\
\hline Cenchrus brownii Roem. \& Schult. & 47377 & * & - & - & - & - & - & - & - \\
\hline Dactyloctenium aegyptium (L.) Willd & d. 47376 & * & - & - & - & * & - & - & - \\
\hline ASTERACEAE & & 33714 & 15.828 & 43.810 & 25.820 & 2762 & 0.093 & 6.670 & 6.290 \\
\hline Delilia biflora (L.) Kuntze & 43329 & 33714 & 15.828 & 43.810 & 24.850 & 2762 & 0.093 & 6.670 & 6.140 \\
\hline AMARANTHACEAE & & 33333 & 6.575 & 52.380 & 22.210 & 4191 & 0.215 & 13.330 & 10.020 \\
\hline Gomphrena vaga Mart. & 43335 & 33333 & 6.575 & 52.380 & 21.040 & 3429 & 0.215 & 13.330 & 9.720 \\
\hline Alternanthera brasiliana (L.) Kuntze & e 43334 & - & - & - & - & 762 & 0.049 & 3.810 & 2.450 \\
\hline ARACEAE & & 9143 & 15.881 & 28.570 & 16.580 & 2476 & 6.117 & 18.100 & 34.290 \\
\hline Alocasia plumbea Van Houtte & 43337 & 1714 & 4.256 & 7.620 & 4.080 & 571 & 1.369 & 4.760 & 7.630 \\
\hline Anthurium affine Schott & 4338 & 3429 & 9.778 & 15.240 & 8.860 & 1619 & 4.677 & 8.570 & 23.030 \\
\hline Anthuri & 47383 & 4000 & 1.847 & 16.190 & 4.760 & 286 & 0.022 & 2.860 & 1.420 \\
\hline MALVACEAE & & 18096 & 2.907 & 42.860 & 14.410 & 2191 & 0.970 & 16.190 & 12.390 \\
\hline $\begin{array}{l}\text { Physaloides stoloniferum (Salzm.) } \\
\text { H. C. Monteiro }\end{array}$ & 43382 & 14667 & 1.940 & 34.290 & 10.610 & 286 & 0.191 & 2.860 & 2.070 \\
\hline $\begin{array}{l}\text { Pseudabutilon spicatum (Kunth) } \\
\text { R.E. Fr. }\end{array}$ & 43383 & 2762 & 0.810 & 9.520 & 2.760 & 381 & 0.064 & 3.810 & 2.050 \\
\hline Malvastrum scabrum Garcke & 43381 & - & - & - & - & 286 & 0.191 & 2.860 & 2.070 \\
\hline Sida glomer & 43386 & 667 & 0.150 & 4.760 & 1.050 & - & - & - & - \\
\hline Sidastrum multiflorum (Jacq.) Fryell & 43384 & - & - & - & - & 1238 & 0.520 & 8.570 & 6.490 \\
\hline Herissantia crispa (L.) Brizi & 43380 & * & - & - & - & * & - & - & 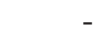 \\
\hline $\begin{array}{l}\text { Pseudomalachra guianensis } \\
\text { (K. Schum.) H. Monteiro }\end{array}$ & 47374 & * & - & - & - & - & - & - & - \\
\hline Wissadula contracta (Link.) R. E. Fr. & 43388 & * & - & - & - & * & - & - & - \\
\hline EUPHORBIACEAE & & 16951 & 3.994 & 40.000 & 14.180 & 5523 & 0.735 & 33.330 & 21.930 \\
\hline Bernardia sidoides Müll. Arg. & 47373 & 10095 & 2.275 & 24.760 & 8.020 & 667 & 0.041 & 5.710 & 2.950 \\
\hline Euphorbia insulana Vell. & 43367 & 3809 & 1.283 & 20.950 & 5.190 & 952 & 0.206 & 9.520 & 5.240 \\
\hline Dalechampia scandens L. & 43366 & 2095 & 0.353 & 11.4300 & 2.650 & 3238 & 0.247 & 20.000 & 11.870 \\
\hline Acalypha multicaulis Müll. Arg. & 43363 & 857 & 0.078 & 2.860 & 0.740 & - & - & - & \\
\hline Phyllanthus niruri L. & 47372 & 95 & 0.002 & 0.950 & 0.180 & 95 & 0.002 & 0.950 & 0.450 \\
\hline Tragia volubilis $\mathrm{L}$. & 47371 & - & - & - & - & 95 & 0.118 & 0.950 & 0.910 \\
\hline Tragia $\mathrm{s}$ & 47391 & - & - & - & - & 476 & 0.118 & 2.860 & 2.040 \\
\hline ACANTHACl & & 17333 & 7.858 & 17.140 & 12.100 & 10191 & 3.620 & 20.950 & 34.520 \\
\hline Pseuderanthemит & 43332 & 15333 & 6.427 & 14.290 & 9.930 & 9048 & 3.143 & 14.290 & 28.490 \\
\hline Ruellia bahiensis (Nees) Morong. & 43333 & 2000 & 1.430 & 3.810 & 1.950 & 667 & 0.456 & 3.810 & 3.900 \\
\hline Ruellia asperula (Nees \& Hook.) & 47379 & - & - & - & - & 476 & 0.021 & 2.860 & 1.660 \\
\hline
\end{tabular}


continuation

\begin{tabular}{|c|c|c|c|c|c|c|c|c|c|}
\hline \multirow[t]{2}{*}{ Families/Species } & \multirow[b]{2}{*}{ N.PEUFR } & \multicolumn{4}{|c|}{2002} & \multicolumn{4}{|c|}{2003} \\
\hline & & $\mathrm{AD}$ & ADo & $\mathrm{AF}$ & VI & $\mathrm{AD}$ & ADo & $\mathrm{AF}$ & VI \\
\hline COMMELINACEAE & & 6286 & 9.305 & 21.900 & 10.930 & 8000 & 2.631 & 23.810 & 28.950 \\
\hline Commelina obliqua Vahl & 43355 & 6286 & 9.305 & 21.900 & 10.450 & 8000 & 2.631 & 23.810 & 28.420 \\
\hline MORACEAE & & 14381 & 1.764 & 20.950 & 8.670 & 10571 & 1.521 & 20.000 & 26.550 \\
\hline Dorstenia asaroides Gardner & 43390 & 14381 & 1.764 & 20.950 & 8.21 & 10571 & 1.521 & 20.000 & 26.110 \\
\hline PORTULACACEAE & & 5143 & 8.091 & 6.670 & 7.090 & 3142 & 0.494 & 5.710 & 7.970 \\
\hline Portulaca oleracea L. & 43406 & - & - & - & - & 2190 & 0.082 & 2.860 & 4.070 \\
\hline Talinum paniculatum Gardner & 43405 & 5143 & 8.091 & 6.670 & 6.940 & 762 & 0.402 & 1.900 & 3.170 \\
\hline Talinum triangulare (Jacq.) Will. & 47381 & - & - & - & - & 95 & 0.002 & 0.950 & 0.450 \\
\hline Talinum sp. & 47392 & - & - & - & - & 95 & 0.007 & 0.950 & 0.470 \\
\hline BROMELIACEAE & & 1238 & 9.073 & 5.710 & 6.440 & 286 & 0.218 & 2.860 & 2.240 \\
\hline Cryptanthus bahianus L. B. Sm. & 43345 & 1238 & 9.073 & 5.710 & 6.310 & 286 & 0.219 & 2.860 & 2.180 \\
\hline ORCHIDACEAE & & 2762 & 2.023 & 10.480 & 3.820 & 1143 & 6.813 & 8.570 & 30.870 \\
\hline Oeceoclades maculata (Lindl.) Lindl. & . 43394 & 2381 & 1.116 & 9.520 & 2.830 & 476 & 3.456 & 3.810 & 15.240 \\
\hline Cyrtopodium holstii L. C. Menezes & 43392 & 381 & 0.907 & 0.950 & 0.760 & 286 & 1.084 & 1.900 & 5.200 \\
\hline Sarcoglottis acaulis (Smyth) Schltr. & 43393 & - & - & - & - & 381 & 2.274 & 2.860 & 10.240 \\
\hline CONVOLVULACEAE & & 4381 & 0.279 & 10.480 & 3.270 & 1428 & 0.140 & 9.520 & 5.810 \\
\hline Evolvulus filipis Mart. & 43352 & 4381 & 0.279 & 10.480 & 3.040 & 190 & 0.037 & 1.900 & 1.030 \\
\hline Jaquemontia hirsuta Choisy & 47380 & - & - & - & - & 286 & 0.039 & 2.860 & 1.490 \\
\hline Ipomoea aristolochiaefolia $\mathrm{G}$. Don & 47386 & * & - & - & - & 952 & 0.064 & 5.710 & 3.400 \\
\hline Merremia aegyptia (L.) Urb. & 43353 & * & - & - & - & - & & - & - \\
\hline SAPINDACEAE & & 1619 & 0.829 & 7.620 & 2.320 & 95 & 0.067 & 0.950 & 0.730 \\
\hline Serjania sp. & 43404 & 1619 & 0.829 & 7.620 & 2.150 & 95 & 0.067 & 0.950 & 0.700 \\
\hline OXALIDACEAE & & 1809 & 0.208 & 8.570 & 2.200 & 1333 & 0.060 & 8.570 & 5.030 \\
\hline Oxalis euphorbioides A. St.-Hil. & 43395 & 1809 & 0.208 & 8.570 & 2.010 & 1333 & 0.060 & 8.570 & 4.840 \\
\hline FABACEAE & & 1810 & 0.352 & 7.620 & 2.100 & 857 & 0.039 & 6.670 & 3.660 \\
\hline $\begin{array}{l}\text { Centrosema sagittatum (Willd.) } \\
\text { Brandegee }\end{array}$ & 43373 & 1143 & 0.196 & 4.760 & 1.200 & 286 & 0.017 & 1.900 & 1.080 \\
\hline $\begin{array}{l}\text { Phaseolus peduncularis W. P. C. } \\
\text { Barton }\end{array}$ & 47387 & 667 & 0.152 & 2.806 & 0.740 & 95 & 0.007 & 0.950 & 0.470 \\
\hline Chaetocalyx longiflora A. Gray & 47378 & - & - & - & - & 190 & 0.009 & 0.950 & 0.600 \\
\hline Desmodium glabrum (Mill.) DC. & 47395 & - & - & - & - & 286 & 0.006 & 2.860 & 1.360 \\
\hline TILIACEAE & & 1048 & 0.142 & 5.710 & 1.430 & 95 & 0.067 & 0.950 & 0.730 \\
\hline Corchorus hirtus L. & 43411 & 1048 & 0.142 & 5.710 & 1.300 & 95 & 0.067 & 0.950 & 0.700 \\
\hline LYTHRACEAE & & & & & & & & & \\
\hline Cuphea prunellaefolia A. St.-Hill. & 43379 & 667 & 0.264 & 5.710 & 1.270 & - & - & - & - \\
\hline ASCLEPIADACEAE & & 667 & 0.069 & 2.860 & 0.750 & - & - & - & - \\
\hline Petalostelma sp. & 47388 & 667 & 0.069 & 2.860 & 0.690 & - & - & - & - \\
\hline CUCURBITACEAE & & 190 & 0.481 & 1.900 & 0.680 & 476 & 0.682 & 4.760 & 4.970 \\
\hline Apodanthera glaziovii Cogn. & 43357 & 190 & 0.481 & 1.900 & 0.630 & 190 & 0.009 & 1.900 & 0.930 \\
\hline Cayaponia sp. & 43358 & - & - & - & 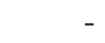 & 286 & 0.673 & 2.860 & 3.930 \\
\hline ALSTROMERIACEAE & & 286 & 0.039 & 2.860 & 0.640 & - & - & - & - \\
\hline Bomarea salsillioides (Mart.) Roem. & 43362 & 286 & 0.039 & 2.860 & 0.570 & - & - & - & - \\
\hline BORAGINACEAE & & 190 & 0.150 & 1.900 & 0.490 & - & - & - & - \\
\hline Heliotropium angiospermum Murr & 43343 & 190 & 0.150 & 1.900 & 0.450 & - & - & - & 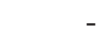 \\
\hline AMARYLIDACEAE & & 190 & 0.104 & 1.900 & 0.470 & 476 & 0.015 & 1.900 & 1.350 \\
\hline Hippeastrum sp. & 47389 & 190 & 0.104 & 1.900 & 0.420 & 476 & 0.015 & 1.900 & 1.310 \\
\hline ARISTOLOCHIACEAE & & 190 & 0.005 & 1.900 & 0.410 & - & - & - & - \\
\hline Aristolochia birostris Duch. & 43340 & 190 & 0.004 & 1.900 & 0.370 & - & - & - & - \\
\hline BEGONIACEAE & & 190 & 0.004 & 1.900 & 0.410 & - & - & - & - \\
\hline Begonia reniformis Dryand. & 43342 & 190 & 0.004 & 1.900 & 0.370 & - & - & - & - \\
\hline
\end{tabular}


continuation

\begin{tabular}{|c|c|c|c|c|c|c|c|c|c|}
\hline \multirow{2}{*}{ Families/Species } & \multirow[b]{2}{*}{ N.PEUFR } & \multicolumn{4}{|c|}{2002} & \multicolumn{4}{|c|}{2003} \\
\hline & & $\mathrm{AD}$ & ADo & $\mathrm{AF}$ & VI & $\mathrm{AD}$ & ADo & $\mathrm{AF}$ & VI \\
\hline PLUMBAGINACEAE & & - & - & - & - & 286 & 0.039 & 2.860 & 1.550 \\
\hline $\begin{array}{l}\text { Plumbago scandens L. } \\
\text { CYPERACEAE }\end{array}$ & 43398 & - & - & - & - & 286 & 0.039 & 2.860 & 1.490 \\
\hline $\begin{array}{l}\text { Cyperus uncinulatus Schander } \\
\text { ex Nees }\end{array}$ & 43359 & $*$ & - & - & - & $*$ & - & - & - \\
\hline LILIACEAE & & & & & & & & & \\
\hline $\begin{array}{l}\text { Sansevieria cf. guineensis (L.) Willd. } \\
\text { LOASACEAE }\end{array}$ & 43376 & * & - & - & - & * & - & - & - \\
\hline $\begin{array}{l}\text { Mentzelia aspera } \mathrm{L} \text {. } \\
\text { PIPERACEAE }\end{array}$ & 43377 & * & - & - & - & * & - & - & - \\
\hline $\begin{array}{l}\text { Peperomia sp. } \\
\text { NYCTAGINACEAE }\end{array}$ & 47382 & * & - & - & - & - & - & - & - \\
\hline $\begin{array}{l}\text { Boerhaavia coccinea Mill. } \\
\text { POLYGALACEAE }\end{array}$ & 43416 & * & - & - & - & * & - & - & - \\
\hline $\begin{array}{l}\text { Polygala paniculata } \mathrm{L} \text {. } \\
\text { SELAGINELACEAE }\end{array}$ & 43403 & - & - & - & - & $*$ & - & - & - \\
\hline Selaginella sulcata (Desv.) Spring. & 47384 & $*$ & - & - & - & - & - & - & - \\
\hline
\end{tabular}

took the form of a reversed " $J$ ". There were significant differences $\left(\chi^{2}=66.4, P<5 \%\right)$ in the diameter distribution curves between the years, although after the third class the proportion of individuals was similar (figure 2B). In the year with superior rainfall, there were more individuals in each diameter class, and $59 \%$ of them had diameters $<1 \mathrm{~cm}$. In the driest year, the percentage of plants with diameters $<1 \mathrm{~cm}$ increased to $72 \%$, demonstrating that these plants responded to water stress with a reduction in stem diameter. Thus in drier years, there is a reduction in absolute plant numbers, as well as in plant height and stem diameter. As a result, herbaceous ground cover diminishes greatly. According to Carvalho et al. (2001) and Sampaio (2003), a thinning of the woody vegetation should allow the herbaceous plants to increase their biomass, due to an increase in light levels. Despite the light factor was not quantified, in 2003 it was observed that shading from the woody plants was reduced (and light penetration therefore greater) and the density and size of the herbaceous plants was significantly reduced. Thus, this study suggest that perhaps light is a secondary factor, in view of the importance of the availability of water in regulating biomass production in the herbaceous stratum.

Population structure of the herbaceous community During the two years of this study, only Phyllanthus niruri, Cyrtopodium holstii, and Apodanthera glaziovii maintained approximately equal numbers of individuals; other species either increased or decreased to varying degrees. Commelina obliqua, for example, increased in numbers moderately, while Dorstenia asaroides, Anthurium afinne, Pseuderanthemum sp., and Oxalis euphorbioides demonstrated moderate decreases. All other species showed drastic decreases. Sida glomerata, Acalypha multicaulis, Bomarea salsillioides, Heliotropium angiospermum, Aristolochia birostris, and Begonia reniformis were not recorded in the driest year (table 1). The drastic alterations observed in these populations were reflected in visually discernable changes in the community organization, suggesting the existence of different regeneration models in different years. Although this study did not attempt to quantify monthly birth and death rates, the yearly differences in population structure suggest that at least two models of regeneration may be involved. One is consistent and independent of seasonality, and is represented by the species that maintained their population levels. The other is inconsistent and dependent on seasonality, and is represented by those species that exhibited considerable alterations in population size.

Although some species disappeared, some new species were encountered in the second year: Alternanthera brasiliana, Malvastrum scabrum, Sidastrum multiflorum, Tragia volubilis, Tragia sp., Ruellia asperula, Portulaca oleracea, Talinum 
triangulare, Talinum sp., Sarcoglottis acaulis, Jacquemontia hirsuta, Chaetocalyx longiflora, Desmodium glabrum, Plumbago scandens, and Cayaponia sp. (table 1). This indicates that the herbaceous community of the "caatinga" harbors two types of flora, one permanent, and another transitory. As such, migration rates must be considered in the construction of dynamic models of the herbaceous stratum, as noted by Araújo (2003) and Araújo et al. (2005b).

The species with the greatest Importance Value (VI) in 2002 were: Pilea hyalina, Dioscorea coronata, Delilea biflora, Gomphrena vaga, Panicum venezuellae, Panicum maximum, Physaloides
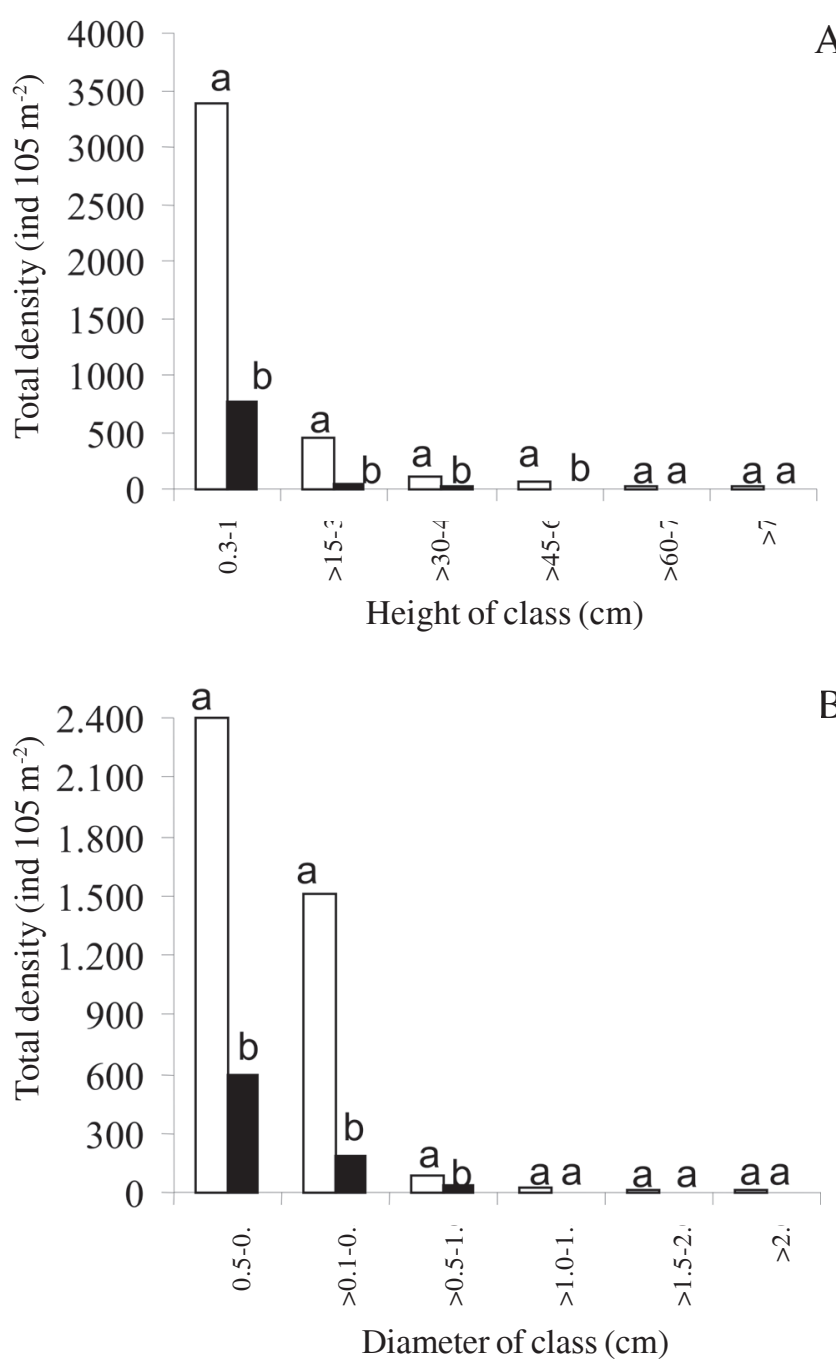

Figure 2. Distribution of the number of individual herbaceous plants in different height (A) and diameter classes (B) from an area of "caatinga" vegetation in Pernambuco, Brazil. Different letters in either of height or diameter size classes indicate significant differences between the number of individuals encountered in 2002 ( $\square$ ) and 2003 (ם) by ChiSquare test, at $5 \%$ probability. stoloniferum, Commelina obliqua, and Dioscorea polygonoides, representing $67 \%$ of the total VI. In 2003, a dry year, the most important species were: Pseuderanthemum sp., Commelina obliqua, Dorstenia asaroides, Dioscorea coronata, Anthurium affine, Panicum venezuellae, Oeceoclades maculata, Dalechampia scandens, and Sarcoglottis acaulis, representing $64 \%$ of the total VI (table 1). These results demonstrate that, independent of rainfall, the herbaceous community tends to have the same of number species influencing its organization.

In general, population structure differed among the microhabitats as well as in different years (table 2). A cluster analysis of the 105 plots indicated that the riparian microhabitat formed a group that was isolated from the level and stony plots. In 2002, the stony group also included some plots from the level (p14, p18, p24) and from the riparian microhabitats (p93). There was a third cluster with a greater degree of similarity, which mixed mainly plots from the level and stony habitats (figure 3). This tendency was matched in 2003. The coffenetic correlation $(r)$ of the matrixes was 0.89 and 0.81 , and the confidence limits of the links were 0.50 and 0.53 in 2002 and 2003, respectively. The isolation of the riparian plots was apparently due to the fact that these are relatively well separated from the stony and level areas, and are generally more humid and continuous. The stony outcrops, on the other hand, are disconnected and occur essentially randomly within the level habitat matrix.

Populations of Aristolochia birostris, Begonia reniformes, Bomarea salsillioides, Centrosema sagittatum, Cryptanthus bahianus, Dorstenia asaroides, Petalostelma sp., Plumbago scandens, Pseuderanthemum sp., and Sarcoglottis acaulis, occur exclusively in the riparian microhabitat. Acalypha multicaulis, Cayaponia sp., Jaquemontia hirsuta, Portulaca oleracea, and Tragia volubilis were recorded only from the stony microhabitat, while Alternanthera brasiliana, Chaetocalyx longiflora, Cyrtopodium holstii, Desmodium glabrum, Malvastrum scabrum, Ruellia asperula and Talinum triangulare were restricted to the level microhabitat. Only a small number of species were common to all three microhabitats, and some of these had larger populations in the level and stony microhabitats: Dalechampia scandens, Delilia biflora, Dioscorea coronata, Gomphrena vaga and Panicum venezuellae. These species were in part responsible for the difficultly in clearly distinguishing between the stony and level microhabitats in the cluster analysis (table 2 and figure 3 ). 


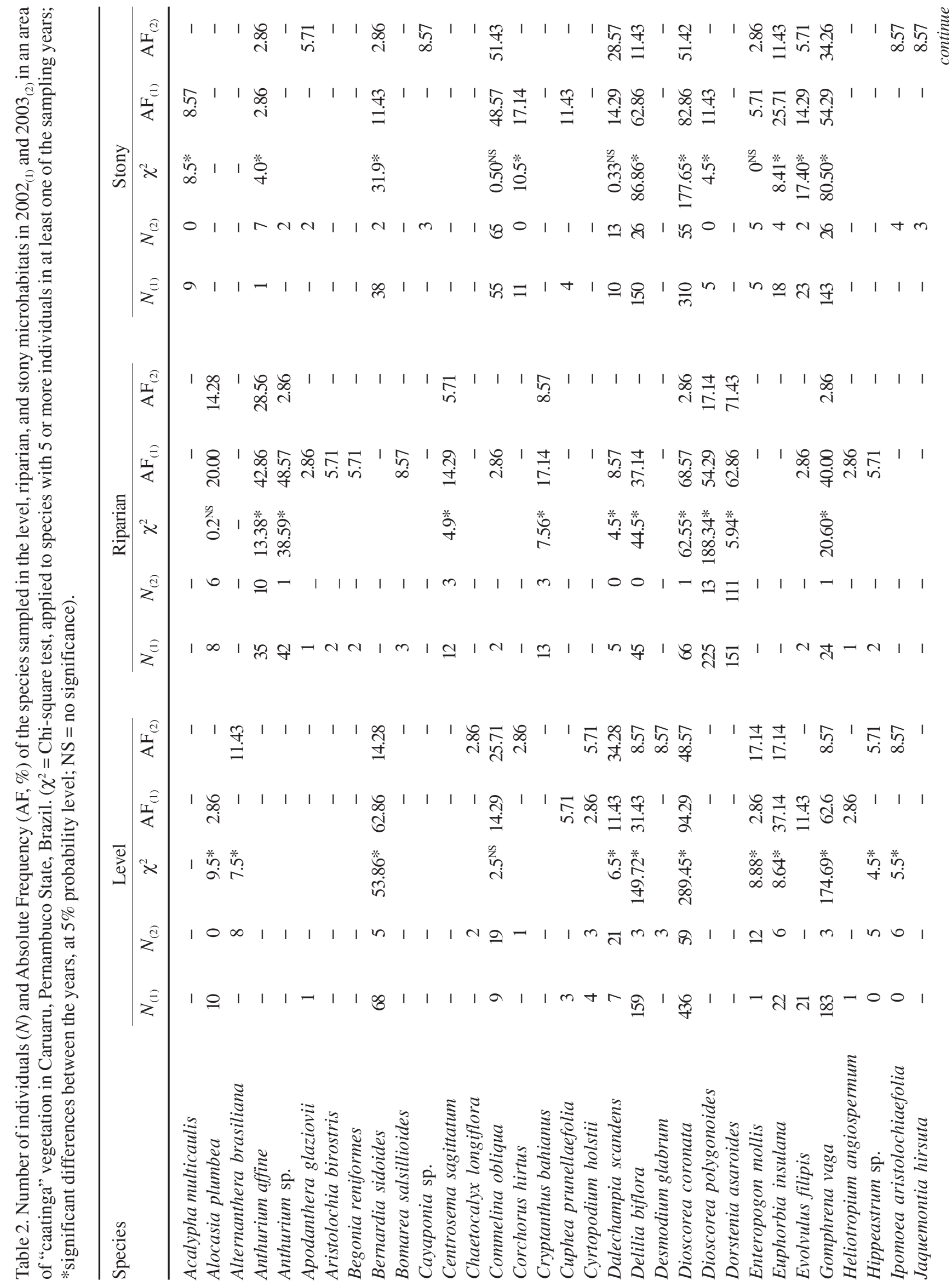




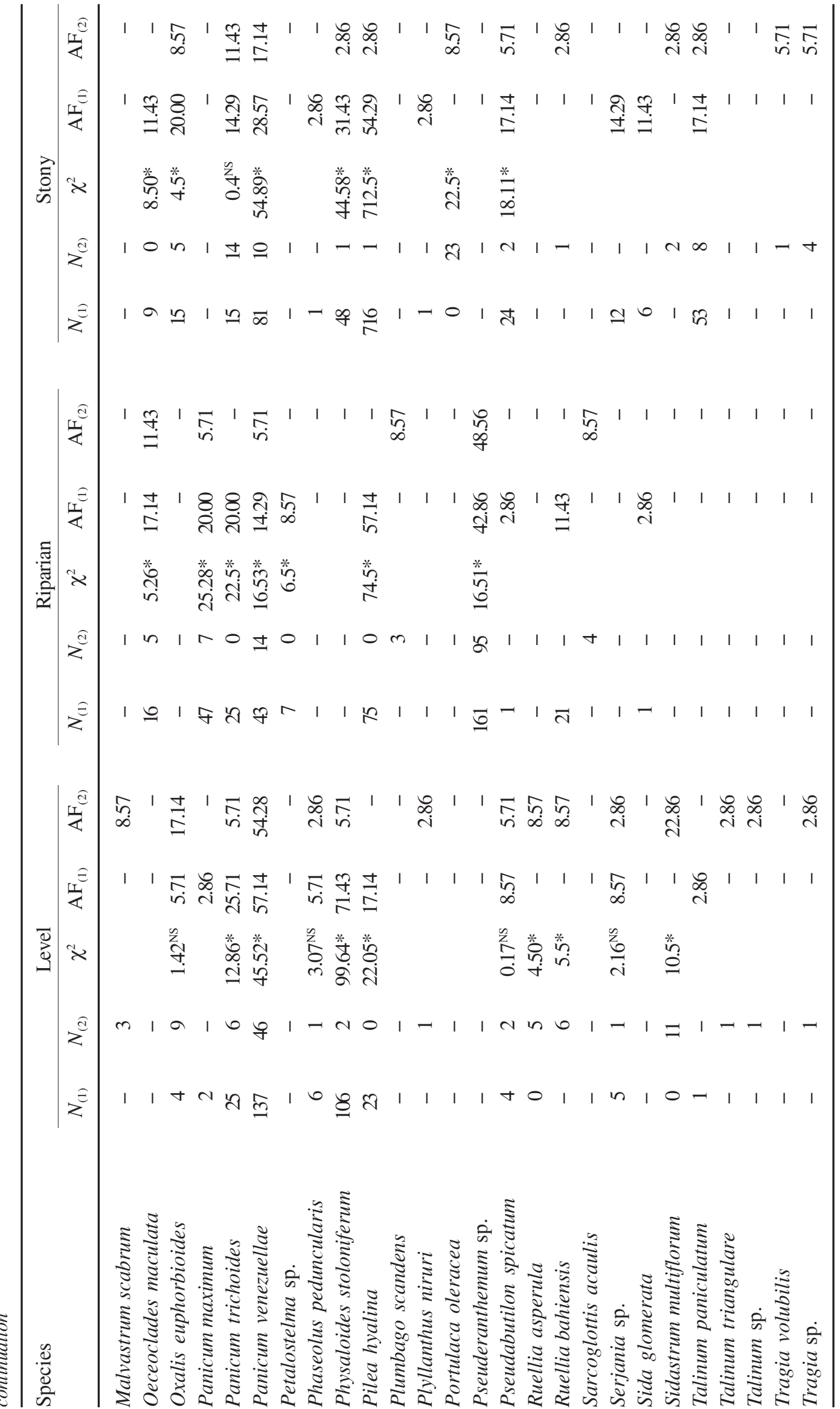




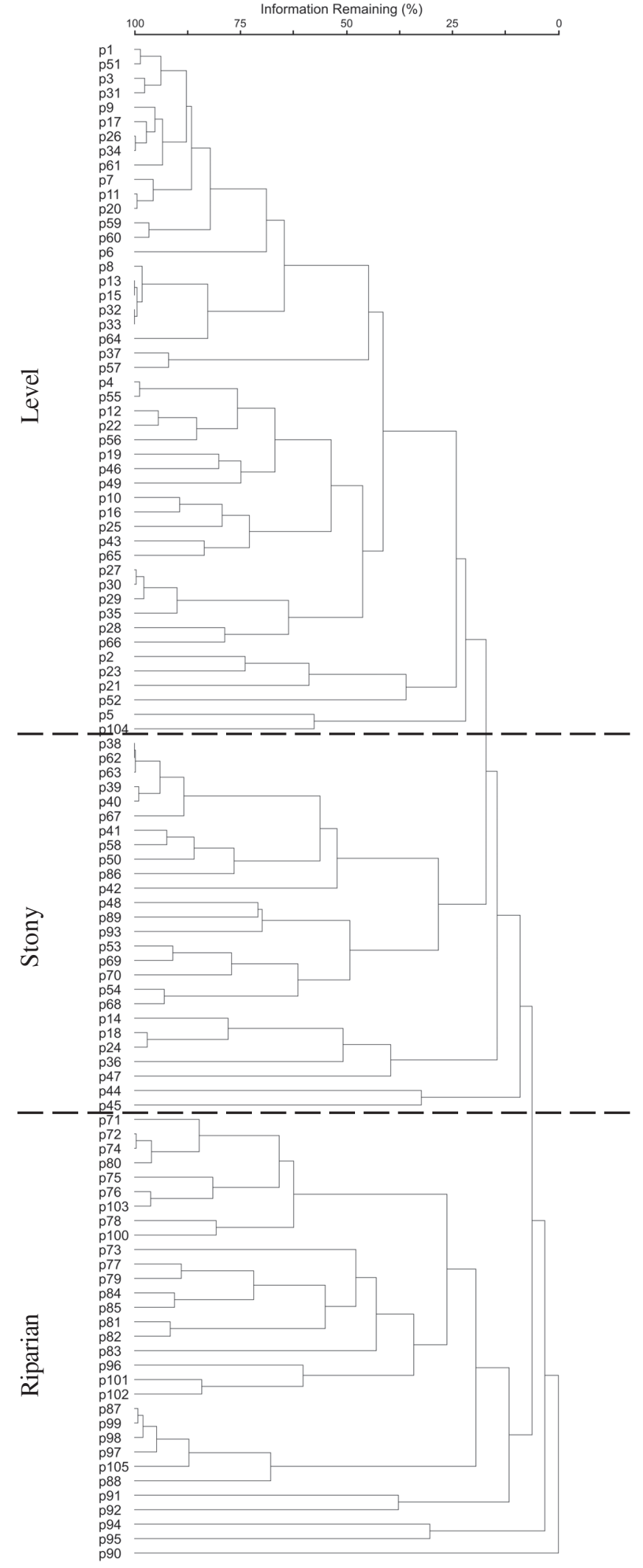

Figure 3. Floristic-structural similarities between the level (p1 to p35), stony (p36 to p70), and riparian (p71 to p105) microhabitats in an area of "caatinga" vegetation in Caruaru, Pernambuco State, Brazil.
The inter-annual climatic variations also resulted in alterations in the sizes and the frequencies of populations within the three microhabitats (table 2). For a majority of the species, the frequency changes observed in the driest year can be explained by the variation in the number of individuals present. However, for some species, frequency was little influenced by alterations in population size: Panicum venezuellae in the level and stony microhabitats; Dorstenia asaroides and Pseuderanthemum sp., in the riparian habitat. These results indicate that recruitment occurred in a large number of plots or the plot number with occurrence of these species was not altered. This suggests that dynamics study will be necessary in order to better comprehend the structure alteration of populations recorded.

Finally, this study concludes that inter-annual climatic variations can alter the structure of herbaceous plant populations and influence community organization in the "caatinga", but the intensity of that influence depends on the biological characteristics of the species in question, and on the microclimate at the site.

Regeneration processes of the herbaceous flora need to be closely monitored and described for longer periods of time, as the appearance and disappearance of species suggests that some populations have "pulsed" demographic cycles. Short-time series studies can induce incomplete or erroneous conclusion about the structure and dynamic herbaceous component of "caatinga" vegetation.

Acknowledgements - The authors would like to thank the Programa de Pós-Graduação em Botânica da Universidade Federal Rural de Pernambuco; CNPq for its financial support and grants (process 478521/2001-4, 478087/04-7 and 301147/2004-3); Dr. Fábio Rubio Scarano and Dr. Everardo Valadares de Sá Barretto Sampaio for their suggestion; and the Estação Experimental da Empresa Pernambucana de Pesquisa Agropecuária - IPA, for access to the research station and its help with our fieldwork.

\section{References}

ALCOFORADO FILHO, F.G., SAMPAIO, E.V.S.B. \& RODAL, M.J.N. 2003. Florística e fitossociologia de um remanescente de vegetação caducifólia espinhosa arbórea em Caruaru, Pernambuco. Acta Botanica Brasilica 17: 287-303.

ARAÚJO, E.L. 1998. Aspectos da dinâmica populacional em floresta tropical seca (caatinga), nordeste do Brasil. Tese de doutorado, Universidade Estadual de Campinas, Campinas. 
ARAÚJO, E.L. 2003. Diversidade de herbáceas na vegetação da caatinga. In Desafios da Botânica brasileira no novo milênio: inventário, sistematização e conservação da diversidade vegetal (E.A.G. Jardim, M.N.C. Bastos \& J.U.M. Santos, eds.). Sociedade Brasileira de Botânica, Belém, p.82-84.

ARAÚJO, E.L. 2005. Estresses abióticos e bióticos como forças modeladoras da dinâmica de populações vegetais da caatinga. In Estresses ambientais: danos e benefícios em plantas (R.J.M. Nogueira, E.L. Araújo, L.G. Willadino \& U.M.T. Cavalcante, eds.). MXM Gráfica e editora, Recife, p.50-64.

ARAÚJO, E.L. \& FERRAZ, E.M.N. 2003. Processos ecológicos mantenedores da diversidade vegetal na caatinga: estado atual do conhecimento. In Ecossistemas brasileiros: manejo e conservação (V. Claudino-Sales, org.). Expressão Gráfica, Fortaleza, p.115-128.

ARAÚJO, E.L. \& FERRAZ, E.M.N. 2004. Amostragem da vegetação e índices de diversidade. In Métodos e Técnicas na Pesquisa Etnobotânica (U.P. Albuquerque \& R.F.P. Lucena, eds.). Livro Rápido, Recife, p.89-137.

ARAÚJO, E.L. \& TABARELLI, M. 2002. Estudos de ecologia de populações de plantas do nordeste do Brasil. In Biodiversidade, conservação e uso sustentável da flora do Brasil. (E.L. Araújo, A.N. Moura, E.V.S.B. Sampaio, L.M.S. Gestinari \& J.M.T. Carneiro, eds.). Imprensa Universitária, Recife. p.135-142.

ARAÚJO, E.L., SILVA, S.I. \& FERRAZ, E.M.N. 2002. Herbáceas da caatinga de Pernambuco. In Diagnóstico da biodiversidade do estado de Pernambuco. (J.M. Silva \& M. Tabarelli, orgs.). SECTMA, Recife, p.183-206.

ARAÚJO, E.L., MARTINS, F.R. \& SANTOS, F.A. 2005a. Establishment and death of two dry tropical Forest woody species in dry rainy seasons in northeastern Brazil. In Estresses ambientais: danos e benefícios em plantas (R.J.M. Nogueira, E.L. Araújo, L.G. Willadino \& U.M.T. Cavalcante, eds.). MXM Gráfica e editora, Recife, p.76-91.

ARAÚJO, E.L., SILVA, K.A., FERRAZ, E.M.N., SAMPAIO, E.V.S.B. \& SILVA, S.I. 2005b. Diversidade de herbáceas em microhabitates rochoso, plano e ciliar em uma área de caatinga, Caruaru-PE. Acta Botanica Brasilica 19: 285-294.

BRUMMITT, R.K. \& POWELL, C.E. 1992. Author of plant names. Royal Botanic Gardens, Kew.

CARVALHO, C.A.L. \& MARCHINI, L.C. 1999. Plantas visitadas por Apis melifera L. no vale do Rio Paraguaçu, Município de Castro Alves, Bahia. Revista Brasileira de Botânica 22: 333-338.

CARVALHO, F.C., ARAÚJO FILHO, J.A., GARCIA, R., PEREIRAFILHO, J.M. \& ALBUQUERQUE, V.M. 2001. Efeito do corte da parte aérea na sobrevivência do marmeleiro (Croton sonderianus Müll.Arg.). Revista Brasileira de Zootecnia 30: 930-934.

FEITOZA, O.M.M. 2004. Diversidade e caracterização fitossociológica do componente herbáceo em áreas de caatinga do nordeste do Brasil. Dissertação de mestrado. Universidade Federal Rural de Pernambuco, Recife.
FERRAZ, E.M.N., RODAL, M.J.N. \& SAMPAIO, E.V.S.B. 2003. Physiognomy and structure of vegetation along na altitudinal gradient in the semi-arid region of northeastern Brazil. Phytocoenologia 33:71-92.

KREBS, C. 1989. Ecological Methodology. Harper \& Row, New York.

LORENZON, M.C.A., MATRANGOLO, C.A. \& SCHOEREDER, J.H. 2003. Flora visitada pelas abelhas eussociais (Hymenoptera, Apidae) na Serra da Capivara, em Caatinga do Sul do Piauí. Neotropical Entomology 32: $27-36$.

MACHADO, I.S., SANTOS, L.M. \& SAMPAIO, E.V.S.B. 1997. Phenology of caatinga species at Serra Talhada, PE, northeastern Brazil. Biotropica 29:57-68.

MAGURRAN, A.E. 1989. Diversidad Ecológica y su medición. Ediciones Vedrà, Barcelona.

MCCUNE, B. \& MEFFORD, M. J. 1999. PC-ORD. Multivariate analysis of ecological data, version 4.0. MJM Software, Gleneden.

MORI, S.A., SILVA, L.A.M. \& LISBOA, G. 1989. Manual de manejo do herbário fanerogâmico. Centro de Pesquisa do Cacau, Ilhéus.

PEREIRA, R.M.A., ARAÚJO FILHO, J.A., LIMA, R.V., PAULINO, F.D.G., LIMA, A.O.N. \& ARAÚJO, Z.B. 1989. Estudos fenológicos de algumas espécies lenhosas e herbáceas da caatinga. Ciência Agronômica 20:11-20.

REIS, A.M.S. 2004. Organização do estrato herbáceo em uma área de caatinga de Pernambuco em anos consecutivos. Dissertação de mestrado, Universidade Federal Rural de Pernambuco, Recife.

SAMPAIO, E.V.S.B. 2003. A caracterização da caatinga e fatores ambientais que afetam a ecologia das plantas lenhosas. In Ecossistemas brasileiros: manejo e conservação (V. Claudino-Sales, org.). Expressão Gráfica. Fortaleza, p.129-142.

SAMPAIO, E.V.S.B., GIULIETTI, A.M., VIRGÍNIO, J. \& GAMARRA-ROJAS, C.F.L. 2002. Vegetação \& flora da caatinga. Associação Plantas do Nordeste - APNE. Centro Nordestino de Informação sobre Plantas, Recife.

SANTOS, M.F.A.V. 1987. Características de solos e vegetação em três áreas de caatinga de Pernambuco. Dissertação de mestrado, Universidade Federal Rural de Pernambuco, Recife.

SILVA, K.A. 2004. Caracterização florística e fitossociológica do componente herbáceo ocorrente em áreas de caatinga do cristalino e sedimentar em Petrolândia, PE. Dissertação de mestrado, Universidade Federal Rural de Pernambuco, Recife.

SHEPHERD, G.J. 1995. Fitopac1. Manual do usuário. Departamento de Botânica, Universidade Estadual de Campinas, Campinas.

ZAR, J.H. 1996. Biostatistical analysis. Prentice Hall, Upper Saddle River. 